\section{Hybridization Parameters Revisited: Solutions Containing SDS}

\author{
BioTechniques 33:54-58 (July 2002)
}

\section{ABSTRACT}

Salt concentration governs nucleic acid hybridization according to the SchildkrautLifson equation. High concentrations of SDS are used in some common protocols, but the effects of SDS on hybridization stringency have not been reported. We investigated hybridization parameters in solutions containing SDS. With targets immobilized on nylon membranes and PCR-or transcription-generated probes, we report that the $50 \%$ dissociation temperature $\left(T_{m} *\right)$ in the absence of SDS was $15^{\circ} \mathrm{C}-17^{\circ} \mathrm{C}$ lower than the calculated $T_{m}$. SDS had only modest effects on $T_{m} *[1 \%(w / v)$ equating to $8 \mathrm{mM} \mathrm{NaCl}]$. RNA/DNA hybrids were approximately $11^{\circ} \mathrm{C}$ more stable than DNA/DNA hybrids. Incom plete homology (69\%) significantly reduced the $T_{m} *$ for DNA/DNA hybrids (approximately $14^{\circ} \mathrm{C}$; $0.45^{\circ} \mathrm{C} / \%$ nonhomology) but far less so for RNA/DNA hybrids (approximately $2.3^{\circ} \mathrm{C}$; approximately $0.07^{\circ} \mathrm{C} / \%$ nonhomology); incomplete homology also markedly reduced the extent of hybridization. On these nylon filters, SDS had a major effect on nonspecific binding. Buffers lacking SDS, or with low salt concentration, gave high hybridization backgrounds; buffers containing SDS, or high-salt buffers, gave reproducibly low backgrounds.

\section{INTRODUCTION}

Hybridization to sequences immobilized on a solid support is commonly employed to detect sequences related to the hybridization probe while excluding more distantly related nucleic acids. Hybridization experiments performed some decades ago generated the following relation between the concentration of monovalent cation and the $\mathrm{T}_{\mathrm{m}}$ of long (1 kb or greater) DNA:

$$
\mathrm{T}_{\mathrm{m}}=16.6 \log \mathrm{M}+0.41(\% \mathrm{G}+\mathrm{C})+81.5
$$

(10), where $\mathrm{M}$ is the monovalent cation concentration (molarity) and \% $\mathrm{G}+\mathrm{C}$ is the percent $\mathrm{G}+\mathrm{C}$ content. For shorter hybrids $(<1 \mathrm{~kb})$, the expression $\Delta \mathrm{T}_{\mathrm{m}}=$ $-820 / 1$ has been employed (12), where 1 is the hybrid length in nucleotides and $\Delta \mathrm{T}_{\mathrm{m}}$ the estimated change in $\mathrm{T}_{\mathrm{m}}\left({ }^{\circ} \mathrm{C}\right)$. Somewhat lower values have been advocated elsewhere, including 500/1 (5). The change in $T_{m}$ due to reduced interstrand homology may be represented by $\Delta \mathrm{T}_{\mathrm{m}}=-(100-\mathrm{h}) \mathrm{t}$, where $\mathrm{t}$ is the change in $\mathrm{T}_{\mathrm{m}} / \%$ nonhomology and $\mathrm{h}$ is the \% homology between the two sequences. Various values have been ascribed to $t$, varying from 0.04 to 4.8 ; a midway value of around $1.2^{\circ} \mathrm{C} / \%$ nonhomology has been proposed (7).

With the introduction of new methods of immobilizing (e.g., nylon mem branes), labeling (e.g., PCR and in vitro transcription), and hybridizing nucleic acids (e.g., buffers containing high concentrations of SDS) $(6,13)$, we wished to validate established hybridization parameters. The effects of SDS were not predictable because increasing $\mathrm{Na}^{+}$ concentrations might be expected to increase the stability of the hybrid; a large and potentially chaotropic dodecylsulfate anion could destabilize hybrids, particularly at high concentrations [7\% (w/v) in Reference 6]. We standardized a protocol to simulate a common hybridization experiment and investigated, in this model, the effect of various parameters on the extent of hybridization and the intensity of background nonspecific hybridization.

\section{MATERIALS AND METHODS}

\section{Nucleic Acids}

Probes and targets were based on approximately 169-nucleotide segments of the mouse Wnt10A, Wnt10B, and Wnt8BB cDNAs [GenBank ${ }^{\circledR}$ accession nos. U61969 and U61970 (14) and AF130349 (8)]. Equivalent segments of Wnt10A, Wnt10B, and Wnt8A (14441606, 166 nucleotides, 69\% G+C; 805-970, 171 nucleotides, $61 \% \mathrm{G}+\mathrm{C}$; and 669-824, 160 nucleotides, 66\% $\mathrm{G}+\mathrm{C}$, respectively) were cloned into pBluescript $^{\circledR}$; the homology between the Wnt10A and Wnt10B segments is $69 \%$. DNA was prepared by a standard $\mathrm{CsCl}$ protocol. Probes were radiolabeled by the incorporation of $\left[{ }^{32} \mathrm{P}\right]$-nucleotides, either by PCR (DNA probes; stan- dard T3 and T7 forward and reverse primers) or by riboprobe transcription from segments cloned into pBluescript; probes were deproteinized by phenol extraction. DNA probes were denatured at $100^{\circ} \mathrm{C}$ for $10 \mathrm{~min}$ before use.

\section{Hybridization}

Conditions were modified from Church and Gilbert (6) (1\% BSA, 1 mM Na 2 EDTA, $0.5 \mathrm{M} \mathrm{NaPO}_{4}$, pH 7.2, $7 \%$ SDS). DNA targets were denatured for $10 \min (0.5 \mathrm{M} \mathrm{NaOH}, 1.5 \mathrm{M} \mathrm{NaCl})$, applied to filters (Hybond ${ }^{\circledR}-\mathrm{N}$; Amersham Biosciences, Little Chalfont, $\mathrm{UK})$, renatured for $10 \mathrm{~min}(1 \mathrm{M}$ Tris$\mathrm{HCl}, \mathrm{pH} 7.4,1.5 \mathrm{M} \mathrm{NaCl}$ ), washed in $2 \times$ SSC, dried, and UV-irradiated (254 $\mathrm{nm})$ before equilibrating in hybridization buffer $\left(0.025 \mathrm{M} \mathrm{NaPO}_{4}, \mathrm{pH} 7.2,1\right.$ mM EDTA, 1\% BSA) containing the appropriate concentration of SDS. The total sodium concentrations were $\mathrm{NaPO}_{4}$ buffer $(25 \mathrm{mM}), \mathrm{pH} 7.2,\left[\mathrm{Na}^{+}\right]$ $=35 \mathrm{mM} ;$ SDS $\left[\mathrm{CH}_{3}\left(\mathrm{CH}_{2}\right)_{10} \mathrm{CH}_{2}{ }^{-}\right.$ $\mathrm{OSO}_{3} \mathrm{Na}, \mathrm{MW}=288 \mathrm{Da}$, $6 \%(\mathrm{w} / \mathrm{v})$, $\left[\mathrm{Na}^{+}\right]=208 \mathrm{mM}$; without allowance for partial dissociation. After prehybridization at $68^{\circ} \mathrm{C}$ for $30 \mathrm{~min}$, the probe was added and incubated overnight. Washing employed hybridization buffer (short washes at room temperature, followed by sequential 5 -min periods at the designated temperatures as specified). Filter segments were dried before liquid scintillation counting.

\section{RESULTS}

We explored the effects of $\mathrm{NaCl}$ and SDS on $\mathrm{T}_{\mathrm{m}}$ and extent of hybridization. This was performed, using 164-nucleotide probes and (plasmid-borne) targets based on the mouse Wnt10A and 10B genes, both for DNA/DNA and RNA/DNA hybrids, and for perfect (100\% identity) and imperfect (69\% identity) hybrids. Target DNA was im mobilized on nylon membranes and hybridized with radiolabeled RNA or DNA probes (prepared by PCR or in vitro transcription) under different salt, temperature, and wash conditions. Standardized hybridization was based on the Church and Gilbert (6) protocol; experiments were performed in the presence of BSA, EDTA, a low concentration of 
Table 1. $\mathrm{T}_{\mathrm{m}}{ }^{*}$ as a Function of SDS and $\mathrm{NaCl}$ Concentration for Perfect and 69\% Homologous Hybrids

\begin{tabular}{|c|c|c|c|}
\hline Conditions & Hybrid & $\begin{array}{l}\mathrm{T}_{\mathrm{m}}^{*}\left({ }^{\circ} \mathrm{C}\right) \\
100 \% \\
\text { Homology }\end{array}$ & $\begin{array}{c}69 \% \\
\text { Homology }\end{array}$ \\
\hline $10 \mathrm{mM} \mathrm{NaCl}$ & $\begin{array}{c}\text { DNA } \\
\text { RNA/DNA }\end{array}$ & $\begin{array}{c}61.5^{a} \\
67\end{array}$ & $\begin{array}{c}42 \\
65.5\end{array}$ \\
\hline $0.6 \%$ SDS & $\begin{array}{c}\text { DNA } \\
\text { RNA/DNA }\end{array}$ & $\begin{array}{l}57.5 \\
63.5\end{array}$ & $\begin{array}{c}48.5 \\
60\end{array}$ \\
\hline $100 \mathrm{mM} \mathrm{NaCl}$ & $\begin{array}{c}\text { DNA } \\
\text { RNA/DNA }\end{array}$ & $\begin{array}{c}72.5^{b} \\
77\end{array}$ & $\begin{array}{l}60 \\
76\end{array}$ \\
\hline $6 \%$ SDS & $\begin{array}{c}\text { DNA } \\
\text { RNA/DNA }\end{array}$ & $\begin{array}{l}68 \\
75\end{array}$ & $\begin{array}{l}53 \\
72\end{array}$ \\
\hline \multicolumn{4}{|c|}{$\begin{array}{l}\text { Values calculated according to References } 10 \text { and } 12 \text { were }{ }^{a} 79^{\circ} \mathrm{C}\left[76^{\circ} \mathrm{C}\right] \text {, } \\
\text { b } 88.5^{\circ} \mathrm{C}\left[87^{\circ} \mathrm{C}\right] \text {; mean differential } \mathrm{T}_{\mathrm{m}}{ }^{*}=\mathrm{T}_{\mathrm{m}}-17^{\circ} \mathrm{C}\left[15^{\circ} \mathrm{C}\right] . \\
\text { Bracketed values allow for incomplete phosphate buffer dissociation. }\end{array}$} \\
\hline
\end{tabular}

$\mathrm{NaPO}_{4}(25 \mathrm{mM}$; a competitor for contaminant radiolabeled inorganic phosphate), and different concentrations of either $\mathrm{NaCl}$ or SDS. After washing, the extent of hybridization was determined by direct scintillation counting.

\section{Effect of SDS and $\mathrm{NaCl}$ on Melting Temperature: Measured $\mathbf{T}_{\mathbf{m}}$ Values Are Less than Predicted}

To determine the effect of SDS on hybrid stability, hybridization was first performed overnight at $68^{\circ} \mathrm{C}$. The effective melting temperature $\left(\mathrm{T}_{\mathrm{m}}{ }^{*}\right)$ was then determined by following hybrid dissociation during serial washing at increasing temperatures. Duplicates were washed (hybridization buffer) at $5^{\circ} \mathrm{C}$ temperature intervals (each wash, 5 min) over the range $50^{\circ} \mathrm{C}-90^{\circ} \mathrm{C}$. Bound radioactivity was determined after each wash. A typical dissociation curve is

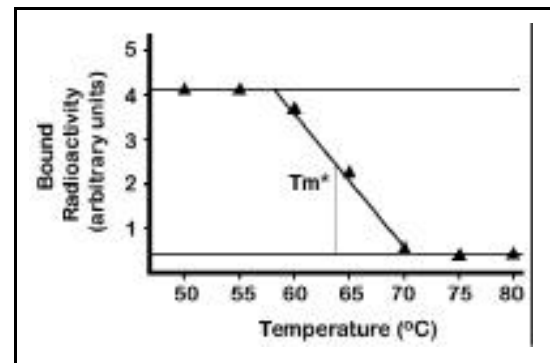

Figure 1. Example of graphic estimation of the $\mathbf{T}_{\mathrm{m}}$ * by loss of bound radioactivity during serial washing $(5 \mathrm{~min})$ at increasing temperature. $\mathrm{T}_{\mathrm{m}} *$ in this example is estimated to be $63.5^{\circ} \mathrm{C}$. plotted in Figure 1. The $\mathrm{T}_{\mathrm{m}}{ }^{*}$ values in each case were calculated graphically from the $50 \%$ dissociation point (Table
1). For the limitations of this technique, see the Discussion section. Both $\mathrm{NaCl}$ and SDS stabilized the hybrids; the change of $\mathrm{T}_{\mathrm{m}}{ }^{*}$ with an increase in $\mathrm{NaCl}$ was as predicted by the Schildkraut-Lifson (10) relation; however, the measured $\mathrm{T}_{\mathrm{m}} *$ values were lower than calculated $\left(15^{\circ} \mathrm{C}-17^{\circ} \mathrm{C}\right)$.

\section{Equivalence of SDS and $\mathrm{NaCl}$}

Graphically plotted $\mathrm{NaCl}$ equivalents were as follows: buffer containing $0.6 \%$ SDS was equivalent, with respect to effects on $\mathrm{T}_{\mathrm{m}}{ }^{*}$, to $16.4 \mathrm{mM} \mathrm{NaCl}$; $6 \%$ SDS was equivalent to $63 \mathrm{mM}$ $\mathrm{NaCl}$. After subtracting the buffer background, this calculated at $7.3 \mathrm{mM}$ $\mathrm{NaCl} / \%$ SDS (0.6\% conditions) and 8.5 $\mathrm{mM} / \%$ SDS (6\% conditions). For further work, a round figure of $1 \%$ SDS = $8 \mathrm{mM} \mathrm{NaCl}$ was adopted; this was substantially less than the calculated figure

\section{if SDS was fully ionized (35 mM).}


Effect of Nonhomology on $\mathbf{T}_{\mathbf{m}}{ }^{*}$ : Relative Stability of DNA/DNA and RNA/DNA Hybrids

Perfect hybrids, as well as RNA/ DNA hybrids, were most stable. As shown in Table 2A, the $\mathrm{T}_{\mathrm{m}}$ * for $69 \%$ homologous DNA/DNA hybrids was reduced by $14^{\circ} \mathrm{C}$ compared to their $100 \%$ identical counterparts $\left(0.45^{\circ} \mathrm{C} / \%\right.$ nonhomology). For RNA/DNA hybrids, the decline in $\mathrm{T}_{\mathrm{m}}{ }^{*}$ was strikingly less, $2.3^{\circ} \mathrm{C}\left(0.07^{\circ} \mathrm{C} / \%\right.$ nonhomology $)$.

RNA/DNA hybrids were considerably more stable than their corresponding DNA/DNA hybrids (Table 2B). The mean differentials were $+5.8^{\circ} \mathrm{C}$ and $+17.5^{\circ} \mathrm{C}$ at $100 \%$ and $69 \%$ homology, respectively. The mean figure, $11.7^{\circ} \mathrm{C}$, is comparable with the commonly adopted figure of $10^{\circ} \mathrm{C}$.

\section{Effects on the Extent of Hybridization}

Hybridization temperature was set to $20^{\circ} \mathrm{C}$ below the calculated $\mathrm{T}_{\mathrm{m}}$ (perfect hybrids) to achieve near-maximum hybridization rate $(1,2,4)$. Hybridization was performed overnight; after extensive washing at room temperature in the same buffers, the absolute quantities of filter-bound radioactivity were determined. Under all conditions tested, nonhomology had a major impact on the extent of hybridization (determined after subtraction of the hybridization background obtained from control filters treated in parallel). With reduced interstrand homology (69\%), filter-bound radioactivity fell to $23 \%$ for DNA/DNA hybrids and to $38 \%$ for RNA/DNA hybrids. In parallel experiments with less homologous hybrids (57\%), the extent of hybridization was further reduced to $10 \%$ for DNA/DNA and $15 \%$ for RNA/ DNA (data not presented). Reduced hybridization rate, in addition to reduced hybrid stability, contributes to the differential hybridization signals generated by perfect and imperfect hybrids.

\section{Hybridization Background}

In the presence of low salt $(10 \mathrm{mM}$ $\mathrm{NaCl}$ ) and in the absence of SDS, significant but variable levels of radioactivity were retained by the filter despite extensive and stringent washing. The inclusion of SDS in the buffer $(0.6 \%$ or
Table 2. $\mathrm{T}_{\mathrm{m}}^{*}$ Decline with Reduced InterStrand Homology; Increased Stability of RNA/DNA versus DNA/DNA Hybrids

\begin{tabular}{|c|c|c|}
\hline \multicolumn{3}{|c|}{ A. Reduced Homology } \\
\hline \multicolumn{3}{|c|}{$\begin{array}{l}\mathrm{T}_{\mathrm{m}}{ }^{*} \text { change }\left({ }^{\circ} \mathrm{C}\right) \text { due } \\
\text { to nonhomology }(69 \% \\
\text { vs. } 100 \% \text { identity) }\end{array}$} \\
\hline \multicolumn{3}{|l|}{ DNA/DNA } \\
\hline $10 \mathrm{mM} \mathrm{NaCl}$ & \multicolumn{2}{|c|}{-19.5} \\
\hline $100 \mathrm{mM} \mathrm{NaCl}$ & \multicolumn{2}{|c|}{-12.5} \\
\hline $0.6 \%$ SDS & \multicolumn{2}{|c|}{-9.0} \\
\hline $6 \%$ SDS & \multicolumn{2}{|c|}{-15} \\
\hline Mean & \multicolumn{2}{|c|}{$\begin{array}{c}-14\left(0.45^{\circ} \mathrm{C} /\right. \\
\% \text { nonhomology })\end{array}$} \\
\hline \multicolumn{3}{|l|}{ RNA/DNA } \\
\hline 10 mM NaCl & \multicolumn{2}{|c|}{-1.5} \\
\hline $100 \mathrm{mM} \mathrm{NaCl}$ & \multicolumn{2}{|c|}{-1} \\
\hline $0.6 \%$ SDS & \multicolumn{2}{|c|}{-3.5} \\
\hline $6 \%$ SDS & \multicolumn{2}{|c|}{-3} \\
\hline Mean & \multicolumn{2}{|c|}{$\begin{array}{l}-2.3^{\circ} \mathrm{C}\left(0.07^{\circ} \mathrm{C} /\right. \\
\% \text { nonhomology })\end{array}$} \\
\hline \multicolumn{3}{|c|}{$\begin{array}{l}\text { B. Elevation of } T_{m}\left({ }^{\circ} \mathrm{C} ;\right. \\
\text { RNA/DNA vs. DNA/DNA) }\end{array}$} \\
\hline \multicolumn{3}{|c|}{$\begin{array}{cc}100 \% & 69 \% \\
\text { Homology } & \text { Homology }\end{array}$} \\
\hline 10 mM NaCl & +5.5 & +23.5 \\
\hline $100 \mathrm{mM} \mathrm{NaCl}$ & +4.5 & +16.0 \\
\hline $0.6 \%$ SDS & +6.0 & +11.5 \\
\hline $6 \%$ SDS & +7.0 & +19.0 \\
\hline Mean & +5.8 & +17.5 \\
\hline
\end{tabular}

$6 \%$ ) or the use of higher salt concentrations $(>100 \mathrm{mM})$ reduced this background substantially (not presented).

\section{DISCUSSION}

We have employed a snapshot approach, simulating hybridization experiments as most commonly performed, to estimate hybridization parameters. Our experiments address the temperature at which $50 \%$ dissociation takes place, defined here as $\mathrm{T}_{\mathrm{m}}{ }^{*}$, rather than the traditional $\mathrm{T}_{\mathrm{m}}$, defined as the tem perature at which $50 \%$ association is observed under equilibrium conditions. $\mathrm{T}_{\mathrm{m}}$ * may be more appropriate for com mon hybridization techniques, including Southern/Northern blotting and DNA microarray hybridization.
Our analysis reconfirms the utility of earlier mathematical analyses of hybridization by Schildkraut and Lifson (10) and by Thomas and Dancis (12), although the $\mathrm{T}_{\mathrm{m}} *$ determined was significantly lower $\left(-17^{\circ} \mathrm{C}\right)$ than that calculated from these equations. This may be due to the method employed for $\mathrm{T}_{\mathrm{m}} *$ determination, involving serial washing for short periods at increasing stringency. First, the graphically obtained value of $\mathrm{T}_{\mathrm{m}}{ }^{*}$ is an estimate; true values may deviate by several degrees. Second, $\mathrm{T}_{\mathrm{m}}$ * reflects the dissociation rate rather than the $\mathrm{T}_{\mathrm{m}}$ as traditionally defined. Third, short wash times should overestimate hybrid stability because the extent of dissociation will be less than during more prolonged incubation (e.g., $1 \mathrm{~h}$ ). However, we saw the reverse effect, with the calculated $\mathrm{T}_{\mathrm{m}}$ (10) substantially exceeding $\left(15^{\circ} \mathrm{C}-17^{\circ} \mathrm{C}\right)$ the values $\left(\mathrm{T}_{\mathrm{m}}{ }^{*}\right)$ measured here. While we have no explanation for this result, the relatively high $\mathrm{G}+\mathrm{C}$ content of the probes could point to a potential error in the calculation of $\mathrm{T}_{\mathrm{m}}$ values according to the $0.41(\% \mathrm{G}+\mathrm{C})$ term in the SchildkrautLifson (10) equation. Also, $\mathrm{T}_{\mathrm{m}}$ values are critically dependent on absolute strand concentration: our experiments use lower concentrations than physical $\mathrm{T}_{\mathrm{m}}$ determinations, predicting lower melting temperatures. Careful reevaluation of this point is warranted. $\mathrm{T}_{\mathrm{m}}$ calculations for short oligonucleotides that take sequence into account (9) offer somewhat different values from Schildkraut and Lifson (10). We also note that polyvalent ions, particularly $\mathrm{Mg}^{2+}$, can make a disproportionate contribution to hybrid stability (15), while under some ionic conditions (e.g., tetramethylam monium chloride) AT pairs can become as stable as GC pairs (16). Previous hybridization experiments commonly used citrate (to $100 \mathrm{mM}$ ) as a chelating agent: EDTA (employed here at $1 \mathrm{mM}$ ) is now more prevalent, but at this concentration its ability to sequester specific polyvalent ions may be limited.

However, for comparative assessments (e.g., $\mathrm{NaCl}$ vs. SDS), changes in $\mathrm{T}_{\mathrm{m}}$ * values (dissociation) may be predictive of changes in $\mathrm{T}_{\mathrm{m}}$ (equilibrium). With the provisos given above, our results suggest that SDS, a common com ponent of hybridization buffers, has no chaotropic (destabilizing) effect on nu- 
cleic acid hybrids at the maximum concentration tested $[6 \%(\mathrm{w} / \mathrm{v})]$. Like $\mathrm{NaCl}$, SDS stabilizes hybrids, with $1 \%$ (w/v) SDS being equivalent to approximately $8 \mathrm{mM} \mathrm{NaCl}$ in its effects on hybrid melting temperature (rather than to $35 \mathrm{mM}$ if fully ionized).

Under our conditions, the $\mathrm{T}_{\mathrm{m}}{ }^{*}$ for related but mismatched DNA/DNA hybrids was reduced by only $0.6^{\circ} \mathrm{C} / \%$ nonhomology, less than the figure of $1.2^{\circ} \mathrm{C}$ adopted previously).

Nevertheless, mismatching significantly reduced the extent of hybridization: at $69 \%$ homology, the extent of hybridization was reduced by a factor of 5 compared with perfect hybrids and fell by a factor of 10 at $57 \%$ homology (not presented). This accords with earlier reports $(3,11)$ that $\mathrm{T}_{\mathrm{m}}$ reduction due to sequence divergence significantly reduces the rate of association. Thus, probe selectivity for perfect matches versus distantly related sequences (e.g., Southern blotting) is most probably due to a reduction in the rate/extent of hybridization (even after $16 \mathrm{~h}$ incubation) rather than to reduced hybrid stability per se.

A significant effect of SDS on hybridization background on nylon filters was observed. Low $(0.6 \%)$ or high (6\%) SDS concentrations equally reduced the background, as did $\mathrm{NaCl}$ $(>100 \mathrm{mM})$. The mechanism is not known. We also noted that the sharpness of the temperature versus dissociation profile was influenced by salt concentration. At high salt, a temperature range of only $10^{\circ} \mathrm{C}$ could span fully hybridized to complete dissociation; at the lowest salt concentrations, tem perature-dependent dissociation was gradual, spanning $25^{\circ} \mathrm{C}$ or more (data not presented).

We suggest that it is advantageous to perform hybridization in the presence of SDS, as proposed previously $(6,13)$, calculating the $\mathrm{T}_{\mathrm{m}}$ using the equivalence figure above $(1 \% \mathrm{SDS}=8 \mathrm{mM} \mathrm{NaCl})$ and selecting the hybridization temperature to be approximately $20^{\circ} \mathrm{C}$ below the $\mathrm{T}_{\mathrm{m}}$. The increased stability of RNA/ DNA hybrids should allow stringency conditions (temperature or equivalent salt) to be increased by $10^{\circ} \mathrm{C}$ without loss of signal, although caution is advocated if the $\mathrm{T}_{\mathrm{m}} *$ is, as we suggest, markedly $\left(15^{\circ} \mathrm{C}-17^{\circ} \mathrm{C}\right)$ below the calculated $\mathrm{T}_{\mathrm{m}}$ (Reference 10 and this work).

\section{REFERENCES}

1.Anderson, M.L.M. and B.D. Young. 1985. Quantitative filter hybridization, p. 73-111. In B.D. Hames and S.J. Higgins (Eds.), Nucleic Acid Hybridisation: A Practical Approach. IRL Press, Oxford.

2.Beltz, G.A., K.A. Jacobs, T.H. Eickbush, P.T. Cherbas, and F. Kafatos. 1983. Isolation of multigene families and determination of homologies by filter hybridization methods. Methods Enzymol. 100B:266-285.

3.Bonner, T.I., D.J. Brenner, B.R. Neufeld, and R.J. Britten. 1973. Reduction in the rate of DNA reassociation by sequence divergence. J. Mol. Biol. 81:123-135.

4.Britten, R.J., D.E. Graham, and B.R. Neufeld. 1974. Analysis of repeating DNA sequences by reasssociation. Methods Enzymol. 29E:363-418.

5.Britten, R.J. and E.H. Davidson. 1985. Hybridization strategy, p. 3-15. In B.D. Hames and S.J. Higgins (Eds.), Nucleic Acid Hybridisation: A Practical Approach. IRL Press, Oxford.

6.Church, G.M. and W. Gilbert. 1984. Genomic sequencing. Proc. Natl. Acad. Sci. USA 81:1991-1995.

7.Lathe, R. 1985. Synthetic oligonucleotide probes deduced from amino acid sequence data. Theoretical and practical considerations. J. Mol. Biol. 183:1-12.

8.Richardson, M., D. Redmond, C.J. Watson, and J.O. Mason. 1999. Mouse Wnt8B is expressed in the developing forebrain and maps to chromosome 19. Mamm. Genome 10:923925.

9.SantaLucia, J., Jr., H.T. Allawi, and P.A. Seneviratne. 1996. Improved nearest-neighbor parameters for predicting DNA duplex stability. Biochemistry 35:3555-3562.

10.Schildkraut, C. and S. Lifson. 1965. Dependence of the melting temperature of DNA on the salt concentration. Biopolymers 3:195208.

11.Sutton, W.D. and M. McCallum. 1971. Mismatching and the reassociation rate of mouse satellite DNA. Nat. New Biol. 232:83-85.

12.Thomas, C.A.J. and B.M. Dancis. 1973. Ring stability. J. Mol. Biol. 77:43-55.

13.Virca, G.D., W. Northemann, B.R. Shiels, G. Widera, and S. Broome. 1990. Simplified northern blot hybridization using 5\% sodium dodecyl sulfate. BioTechniques 8:370-371.

14.Wang, J. and G.M. Shackleford. 1996. Murine Wnt10a and Wnt10b: cloning and expression in developing limbs, face and skin of embryos and in adults. Oncogene 13:15371544.

15.Willams, A.P., C.E. Longfellow, S.M. Freier, R. Kierzek, and D.H. Turner. 1989. Laser temperature-jump, spectroscopic, and thermodynamic study of salt effects on duplex formation by dGCATGC. Biochemistry 28:4283-4291.

16.Wood, W.I., J. Gitschier, L.A. Lasky, and R.M. Lawn. 1985. Base composition-independent hybridization in tetramethylammonium chloride: a method for oligonucleotide screening of highly complex gene libraries. Proc. Natl. Acad. Sci. USA 82:1585-1588.
We would like to thank Melville Richardson for advice and assistance. This work was supported by the BBSRC and DEFRA. Address correspondence to Dr. Richard Lathe, Dept. Biomedical Sciences, Faculty of Medicine, University of Edinburgh, Hugh Robson Building, George Square, Edinburgh EH8 9XD, UK.e-mail: rlathe@ed.ac.uk

Received 9 January 2002; accepted 13 March 2002.

Ken Rose, John O. Mason,
and Richard Lathe
University of Edinburgh,
Edinburgh, UK

\section{RT-PCR Heteroduplex Analysis Permits Differ- entiation of Transgene and Host Gene Expres- sion in a Transgenic Animal Model}

BioTechniques 33:58-66 (July 2002)

\section{ABSTRACT}

In transgenic animal models, the conservation of DNA sequences between the transgene and the host wild-type gene can complicate the evaluation of the expression of each gene. The potential for gene silencing may complicate matters further. Here we report the use of RT-PCR heteroduplex analysis to differentiate the expression of a transgene and its homologous wild-type, even when these genes are very similar in their respective DNA sequences. We designed RT-PCR primers to amplify identically sized 243-bp fragments within the DNA binding domain of the $\mathrm{p} 53$ gene from both human and mouse mRNA samples. Ten samples from human $\mathrm{p} 53$ (273H) transgenic mice and 10 samples from wild-type controls were tested. Heteroduplex bands were formed in all transgenic samples but were absent from all wild-type samples. In addition, RT-PCR heteroduplex analysis was 